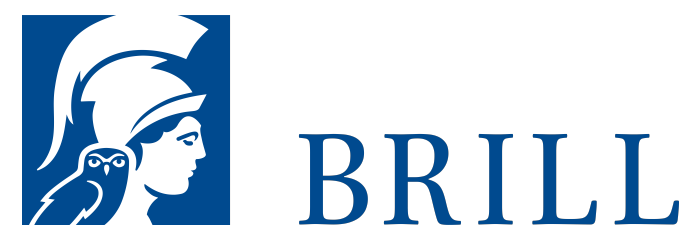

\title{
Literatur und Kultur im Deutschland der Frühen Neuzeit
}

\section{Gesammelte Studien}

Author: Klaus Garber

Die politisch >verspätete Nation $<$ (Helmuth Plessner) ist auch literarisch ein Nachzügler. Drei Jahrhunderte nationalsprachiger Literatur liegen hinter den westeuropäischen Kulturnationen, bevor Deutschland zu Beginn des 17.Jahrhunderts den Anschluss an die weitfortgeschrittenen Nationen der Romania, Englands und der Niederlande findet.

Zwischen Celtis und Lessing wird mehr als dreihundert Jahre unter dem Einfluss der Antike und der europäischen

Renaissance gedacht und gedichtet. Der ständige Vergleich mit den europäischen Vorgängern macht die geschichtliche Rekonstruktion der deutschen frühneuzeitlichen Literatur zu einem faszinierenden Kapitel europäischer Kulturgeschichte. Die vorliegenden Essays beschreiben diesen Weg in der einzig gemäßen Art: als Formanalyse einzelner Werke. Ob es um die calvinistisch beeinflusste Formation der deutschen Literatur oder ihre Stellung im historischen Kontext der Deutschen, die Assimilation der europäischen Arkadienutopie im deutschen Gewande, die Stellung des frühneuzeitlichen Autors im Spannungsfeld von Stadt und Hof, Zunftbürgertum und Patriziat, Adel und Fürstentum geht - immer tritt die spezifisch deutsche Variante im europäischen Kontext nur durch den Blick über die Grenzen hervor.

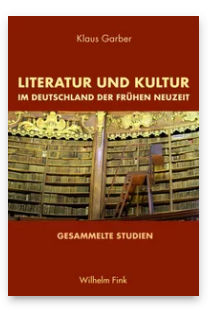

Pages: 994

Seiten

Language:

German

Subjects:

German,

Literature and

Cultural Studies

Publisher: Brill |

Fink

E-Book (PDF)

Released online: 16 Sep 2019

ISBN: 978-3-

8467-5501-3

List price

Hardback

Publication date: 11 Aug 2017

ISBN: 978-3-

7705-5501-7

List price 
Klaus Garber, geboren 1937 in Hamburg, ist Professor für Literaturtheorie und Geschichte der Neueren Literatur an der Universität Osnabrück und Direktor des dortigen Interdisziplinären Instituts für Kulturgeschichte der Frühen Neuzeit.

For more information see brill.com

Order information: Order online at brill.com +44330 3330049 | customerservices@brill.com Submission information: brill.com/authors

Titles published by Brill | Fink, Brill | mentis or Brill | Schöningh: +49(o)71 5413279216 | brill@brocom.de 